\title{
Mekonyum Aspirasyon Sendromu ve Yaklaşımındaki Yenilikler
}

Meconium Aspiration Syndrome and Innovation in the Approach

\author{
Handan Hakyemez TOPTAN ${ }^{1}$, Nilgün KARADAĞ ${ }^{1}$, Güner KARATEKİN ${ }^{1}$ \\ 1. Zeynep Kamil Eğitim Araştırma Hastanesi Yenidoğan Yoğun Bakım Ünitesi, İstanbul
}

$\ddot{O Z E T}$

Mekonyum aspirasyon sendromu tanım olarak mekonyum boyalı amniyotik sivi ile doğan yenidoğanlarda başka bir nedenle bağll olarak açıklanamayan solunum sikıntısı sendromu olarak tanımlanmaktadır. Daha çok term ve posttermlerin sorunudur ve oksidatif süreçten geçen yenidoğanlarda yenidoğan yoğun bakım gereksinimini arttırır. Mekonyum aspirasyon sendromunda (MAS) akciğer hasarının mekanizması oldukça karmaşıktır. Mekonyumun havayollarını tıkaması, ventilasyon ve gaz değişiminde aksaklıklar, sürfaktanın inaktivasyonu, kimyasal pnömoni ve pulmoner hipertansiyon bu karmaşık mekanizma ile ilişkilidir. Bu yazıda mekonyum aspirasyon sendromu ile doğan bebeklerin tanı ve tedavisindeki yaklaşımlar son güncel bilgiler ışı̆̆ında gözden geçirildi.

Anahtar Kelimeler: mekonyum aspirasyon sendromu; tedavi; yenidoğan

\section{ABSTRACT}

Meconium aspiration syndrome is as definition a respiratory distress syndrome in newborns born to meconium stained amniotic fluid which cannot be explained with any other reasons. It is mostly a problem of terms and postterms which passing oxidative process and increased the requirement for neonatal intensive care unit (NICU). The mechanism of lung injury at meconium aspiration syndrome (MAS) is quite complex. Blocking of the airway with meconium, ventilation and gas exchange defects, surfactant inactivation, chemical pneumonitis and pulmonary hypertension are associated with this complex mechanism. In this article is the approach of babies born with meconium aspiration syndrome in the light of current knowledge revised.

Keywords: meconium aspiration syndrome; treatment; newborn

\footnotetext{
İletişim:

Sorumlu Yazar: Dr. Handan Hakyemez TOPTAN

Adres: Zeynep Kamil Eğt. Arş. Hastanesi Yenidoğan Yoğun

Bakım Ünitesi, İstanbul

E-Posta: hhandan98@hotmail.com

Makale Geliş: 22.02.2016

Makale Kabul: 31.05.2016

DOI: http://dx.doi.org/10.16948/zktipb.237216
}

\section{GİRIŞ}

Mekonyum aspirasyonu, fetal hipoksik iskemik stres sonucu tetiklenen intestinal peristaltizmle mekonyum pasajının gerçekleşmesi, amniyotik sıvının mekonyum ile kontaminasyonu ve gasping sonucu akciğerlere nüfuz etmesi ile ortaya çıkan bir inflamatuar zincir kaskatıdır. Zamanında fark edilememesi halinde mortalitesi oldukça yüksektir (1). Mekonyum intrauterin dönemde steril olup tükürük, mide, pankreas, intestinal sekresyonlar, mukus, safra, safra asitleri, hücresel artıklar, lanugo tüyleri, fetal kan içeriğinden oluşur. Postnatal dönemde bakteriler steril kolona inokule olmaya başlar. Son dönemlerde yapılan çalışmalarda $\% 23$ oranında mekonyumun steril olmadığı bildirilmektedir (2). Sağlıklı zamanında doğan bir yenidoğanda mekonyum çıkışı ilk 24-48 saatler arasında gerçekleşir. Doğum öncesi mekonyum çıkışı, tartışmalı olmakla birlikte bebeklerde fetomaternal stresin bir işareti olarak kabul edilir (3). Mekonyum aspirasyon sendromu (MAS) tanım olarak mekonyum boyalı amniyotik siv1 ile doğan yenidoğanlarda başka bir nedene bağlanamayan solunum sikintisı sendromu olarak tanımlanmaktadır. Daha çok term ve posttermlerin bir sorunu olup oksidatif sürecekten geçen yenidoğanlarda yoğun bakım ünitesi (YBÜ) gereksinimini arttıran morbiditesi oldukça yüksek bir sorundur (4). Günümüzde MAS'1n patofizyolojisi ve tedavisinde önemli gelişmeler sağlanmış olmasına rağmen intrauterin veya antenatal dönemde başlayan inflamatuar süreci kontrol altına alacak, mortalite ve morbiditeyi azaltacak tedaviler konusundaki çalışmalar halen sürmektedir (5).

Sıklık ve Risk Faktörleri: Tüm doğumların yaklaşık \%8-15'inde amniyotik sıvı mekonyum ile kontamine iken bu bebeklerin ancak \%510'unda MAS gelişir (6). Pretermlerde bildirilen s1klığ1 \%5.1 iken, termlerde \%16.5, posttermlerde \%27.1'dir. Bu s1klık bebeğin gebelik haftası (GH) ile doğrusal olarak artmaktadır. Gebelik yaşı ilerledikçe fetusun mekonyum çıkarma olasılığ 1 artarken, 31.GH'nın altında nadirdir. Postmatürite $(\mathrm{GH}>42)$, gebelik haftasına göre düşük doğum ağırlığı, hipoksi, preeklampsi, 
annenin kronik hipertansiyonu, sigara içimi, solunum veya kardiyovasküler sistem hastalıklarının MAS riskini arttırdığı görülmüştür (7).

Patofizyoloji: Mekonyum temel üç bileşeni intestinal sekresyonlar, mukoza epitel hücreleri ve amniyon sivisinın solid elementleri olan, \%85-95'i sudan oluşan yenidoğan intestinal sisteminin oluşturduğu ilk ürünüdür. Fetal hayatta 10-12. haftalarda üretilmeye bașlanır (1). Amniyotik siviya 20.GH'na kadar zaman zaman olan mekonyum partikül pasaj1, anal sfinker tonusunun gelişmesi ile 20.GH'nda bir duraklama gösterir ve 20-34.GH arasında görülmesi nadirdir. Gebelik yaşının ilerlemesi nöronal miyelinizasyonun artması, parasempatik sistemin olgunlaşması ve fetusta peristaltizmi sağlayan 'motilin' hormonunun artmasiyla mekonyum pasajı gerçekleșir. Başın ve/veya göbek kordonunun sıkışmasına bağlı hipoksi ve sekonder vagal uyarı artışı, anal sfinkterde gevşemeye ve peristaltizmin artışına yol açarak amniyotik s1vıya mekonyum çıkışına yol açabilir $(3,4)$. Ayrıca intrauterin strese yol açan annenin plasental yetmezliği, hipertansiyonu, preeklampisi, oligohidroamniosu, kokain, nikotin ilaç bağımlılığ 1 da distrese yol açarak amniyon sıvısına mekonyum çıkıșına sebep olabilir. Amniyon sıvısında mekonyum varlığı fetusta hipokse- mi, asidoz ve asfiksi gelişimine zemin hazırlar $(5,6)$. Mekonyumun intrauterin dönemde fetüs tarafindan aspirasyonu enfeksiyon ve inflamasyon kaskatını tetiklemektedir (7). Mekonyumu oluşturan çeșitli kimyasal komponentlerin inflamasyon ve apopitoza yol açarak çoklu organ hasarına neden olduğunu ileri sürülmektedir.

Hava yollarınının mekanik blokajı, sürfaktanin inaktivasyonu ve pulmoner hipertansiyon MAS'a bağlı solunum sıkıntısı sendromunun temel bileşenlerini oluşturmaktadır (Şekil 1) $(8,9)$. Deneysel olarak MAS'ta en çok çalıș1lan mediatörler sitokinler, kompleman sistem, reaktif oksijen radikalleri (ROS), nitrik oksit (NO), araşidonik asit metabolitleri ve transkripsiyon faktörleridir. Sitokinler hücreler arası sinyal molekülleri olup büyük ölçüde Toll-like reseptör (TLR) ailesi tarafindan üretilmektedir. Mekonyumlu amnion sıvisında tümör nekroz faktör alfa (TNF- $\alpha)$, IL-1 $\beta$, IL-6, IL-8 ve IL13 düzeyleri yüksek bulunmuștur $(9,10)$. Mekonyumdaki proinflamatuar maddelerin sebep olduğu doğrudan inflamasyon dişında dolaylı yollardan da alveol hücrelerinden sitokin sal1nımını sağlayarak akciğer ve diğer organ sistemlerinde hasara yol açtığ (11). Mekonyum aspirasyon sendromunda inflamasyon kaskatının başlangıcı CD14 aracılı̆̆

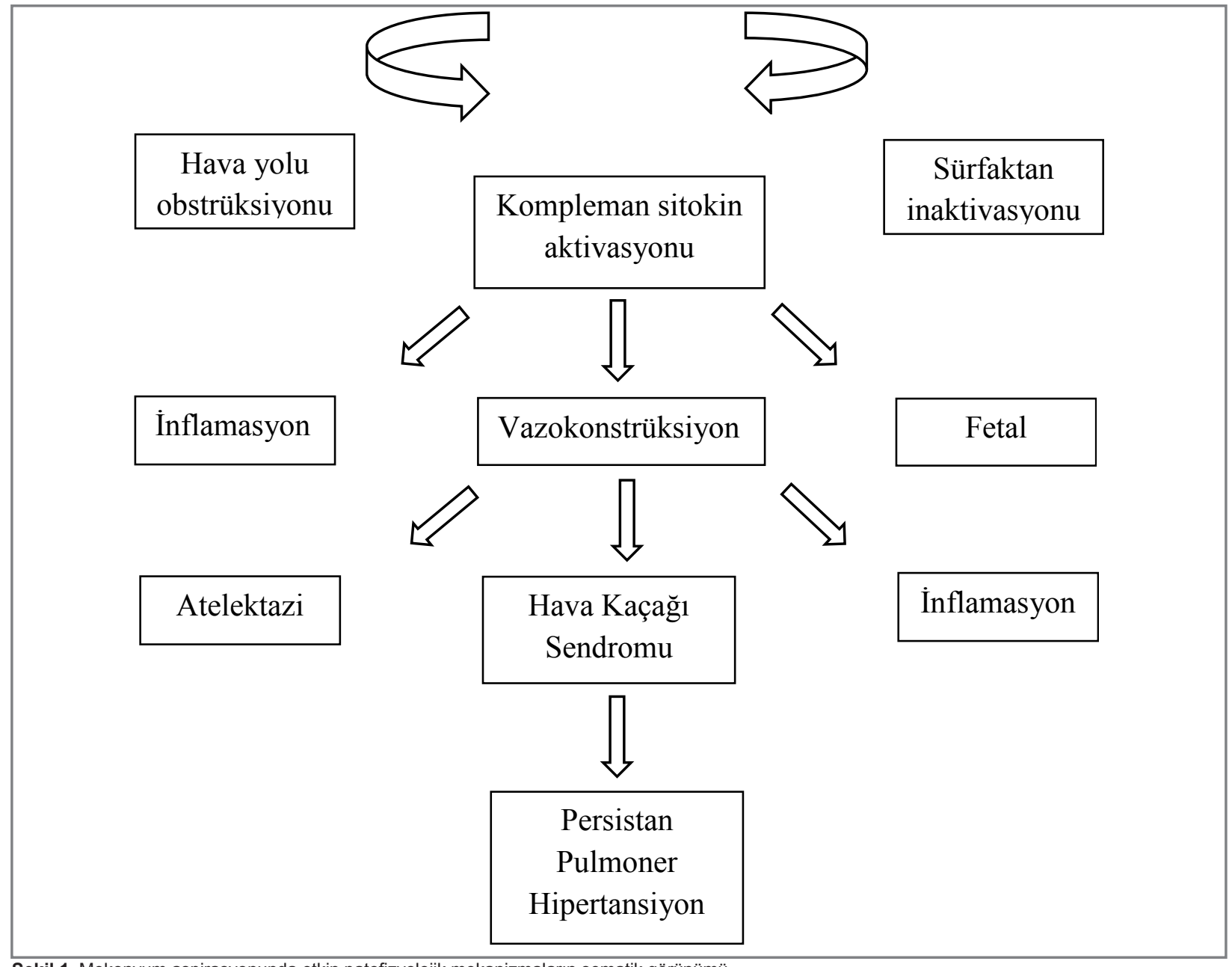


ile TLR aktivasyonu gerçekleşir. Mekonyum ile indüklenen hasar nötrofil aktivasyonu, yüzey aktivasyonu belirteçleri, oksidatif hasar, C5a anafilatoksin ve kompleman sistemi tarafindan olușturulmaktadır (12). Sitokinler ve tromboksan A2, angiotensin II gibi vazokonstrüktörlerin salgılanmasındaki artış mekonyumun havayollarını tıkamas1, ventilasyon ve gaz değişimindeki aksaklıklar, sürfaktanın inaktivasyonu, kimyasal pnömoni ve pulmoner hipertansiyon gelişiminde etkindir (13). Toll-like reseptör ve kompleman sistemi iki ana tehlikeyi tanıma sistemi olup aktivasyonu ile sekonder inflamatuar süreci başlatılır. Lökosit aktivasyonu ve sitokinler aynı zamanda ROS, adhezyon moleküllerinin ekspresyonunu sağlar.

Kanda artan Lökotrien-B4, lökotrien-D4, endotelin-1 ve prostoglandin-E2'nin düzeyleri persistan pulmoner hipertansiyon gelişimine zemin hazırlar (12-14). Mekonyumun içeriğindeki otokoidlerin dolaşıma geçmesiyle de fetal akciğerler, beyin ve diğer organlarda vazokonstrüksiyon gelişir ve fetüste distrese hatta ölüme yol açabilir. Mekonyum ile indüklenen nötrofil aktivasyonu, ölçülen yüzey aktivasyonu belirteçleri üzerindeki araștırmalar sürmektedir. Geliștirilen TLR4/MDR 2 inhibitör synobakteriyel (CyP) isimli ürünler MAS' ta CD14 arac1lığı ile TLR aktivasyonunu inhibe eder $(14,15)$.

\section{TANI}

Mekonyum boyalı bebek (MBB) veya MAS tanısı ayrıntılı bir öyküden başlar, klinik ve radyolojik bulgularla desteklenir.

1. Klinik Tanı: Mekonyum aspirasyon sendromu için tanı kriterleri: Mekonyum boya- l1 olarak doğan bir yenidoğanda solunum sıkıntıs1 (takipne, retraksiyon) olması; oksijen satürayonlarının \%92'nin üzerinde tutabilmek için oksijen gereksinimi olması; oksijen gereksiniminin hayatın ilk iki saatinde başlayıp 12 saate kadar sürmesi, konjenital hava yolu, akciğer ve kalp hastalığının olmaması olarak tanımlanır $(16,17)$. Fizik muayene bebeğin farklı vücut kısımlarının mekonyumla boyalı olması bebeğin mekonyuma maruziyet süresi hakkında fikir verebilir. Sadece göbek kordonunun boyanmıș olmasi 1/2-1 saatlik maruziyeti, tırnakların boyanmıș olması 4-6 saatlik, verniks kazeozanın boyanmış olması ise 12-14 saatlik maruziyeti düşündürür. Mekonyum aspirasyon sendromunda solunum sistemi bulgularının ağırlığına göre MAS'1 derecelendiren bir siniflama mevcuttur; Hafif MAS: 48 saatten daha kısa süreli $\% 40$ 'dan daha az oksijene ihtiyacı duyulması, Orta şiddette MAS: 48 saatten daha uzun süre $\% 40$ 'tan daha fazla oksijene ihtiyaç duyulması ve hava yolu kaçaklarının olmaması, Şiddetli MAS: 48 saatten daha uzun süre mekanik ventilasyona ihtiyaç olması ve eşlik eden; Persistan pulmoner hipertansiyon (PPHN) olmas1 (18).

2. Radyolojik Tanı: Mekonyum aspirasyon sendromunun erken döneminde radyografide havalanma artışı, diyaframda düzleşme, düzensiz lineer ya da yama tarzı atelektazi alanları gözlenirken, ağır olgularda 48-72 saat sonra pnömoni ve interstisyel ödeme bağlı yaygın, kaba, homojen opasiteler görülür. MAS'l 1 hastaların \% 10-30'unda hava kaçakları da gelişebilir.

Pnömomediastinum hafif olgularda 24-48 saatte, ağır olgularda ise 7-10 gün içerisinde düzelir. Radyolojik bulguların tamamen düzelmesi haftalar sürebilir (Resim 1-2) $(5,16,18)$.

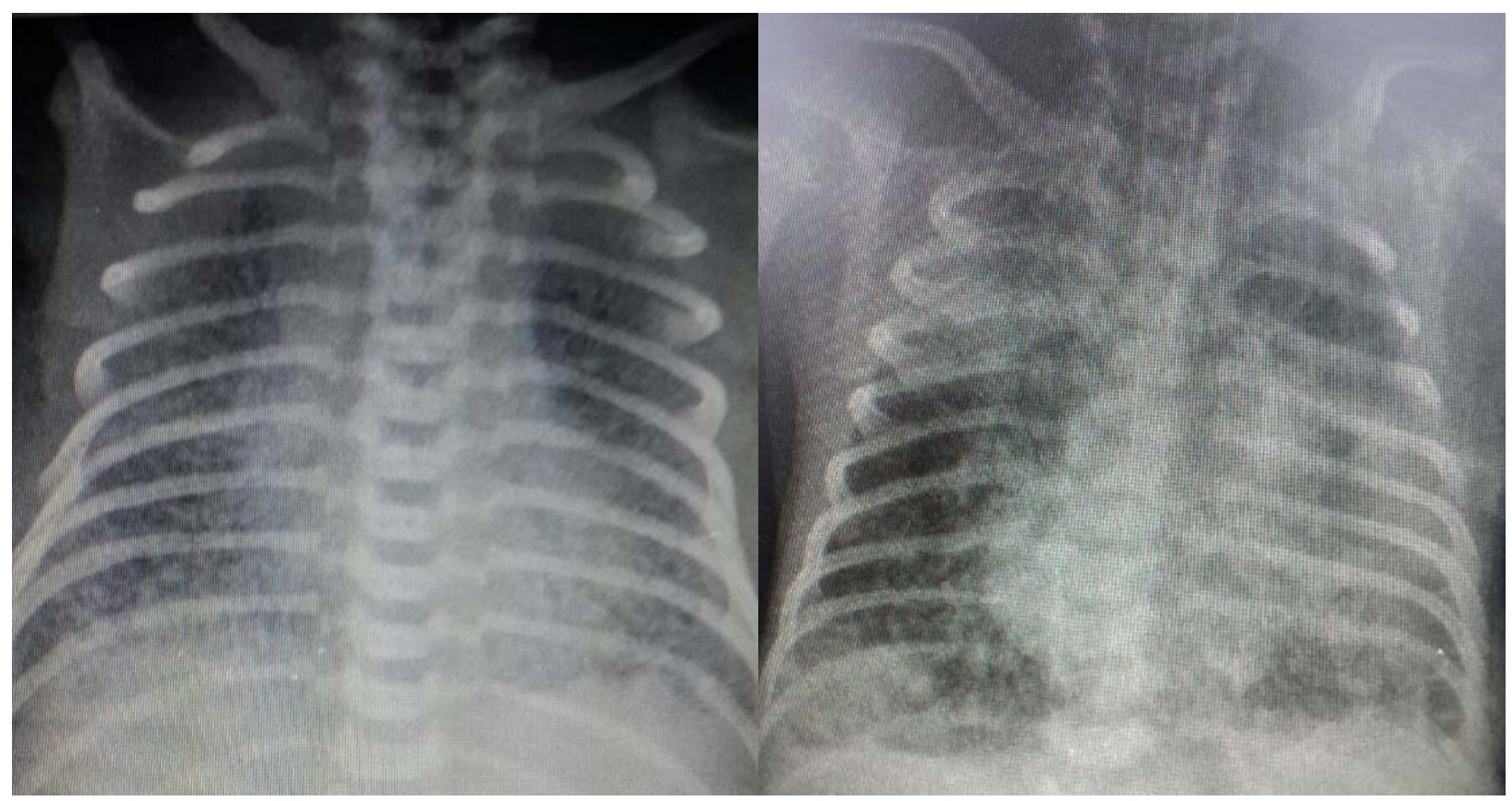

Resim 1-2. Kırk haftalık bir olgumuzda mekonyum boyalı doğduktan sonra ilk 6 saatte gelişen havalanma artışı, diyaframda düzleşme, düzensiz lineer ve yama tarzı opasitelere ait direkt grafi görünümü. 


\section{TEDAVI}

1. Antenatal Yaklaşımda Dikkat Edilmesi Gerekenler: Mekonyum aspirasyonun önlenmesinde dikkatli antenatal izlem ve postmatür gebeliklerin önlenmesi takip ve tedavide büyük öneme sahiptir. Antenatal dönemde amniyon sivisinda mekonyum saptanan gebelerde yakın fetal distres takibi ve hızlı müdahale dışında yapılabilecekler sınırlıdır $(1,3,6)$. Bu noktada amniyoinfüzyon uygulamaları dikkat çekmektedir.
Literatürdeki çalıșmalar amniyoinfüzyon sonrası mekonyumun vokal kordlar altında görülme sıklığının ve MAS sıklığının azaldığını bildirmekle birlikte günümüz verileri 1şığında bunu tam olarak söylemek ve önermek mümkün değildir (19).

\section{Postnatal Yaklaşımlarda Dikkat Edil-} mesi Gerekenler: Doğum odasında doğru yaklaşımlarda bulunmak bir diğer önemli noktadır. Mekonyum boyalı amniyotik sıvı (MBAS) ile doğan her bebeğe rutin intratrakeal aspirasyon

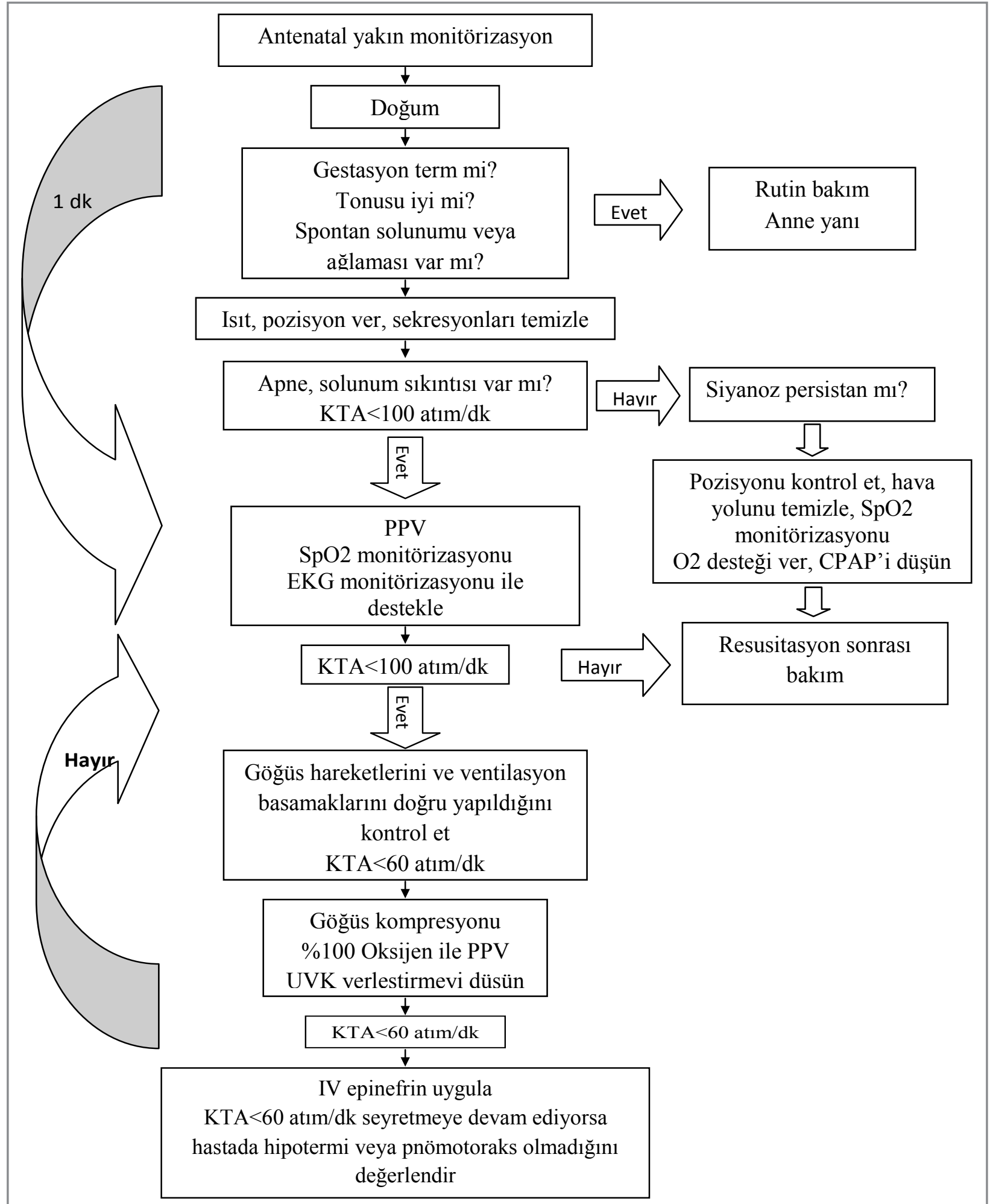


uygulamasından MAS sıklığını azaltmadığının gösterilmesi ve bebeklerde düşük APGAR skorlarına yol açması nedeniyle vazgeçilmiștir $(5,21)$. Eğer bebek mekonyumla boyanmış sıv1 ile doğmuş, spontan solunumu varsa, kas tonusu iyiyse ve kalp atım hızı >100 atım/dakika ise yalnızca puar ağız ve burunda kalmış olan mekonyum ve sekresyonların temizlenmesi yeterlidir. Orofarengeal aspirasyonda hasta radyant 1sitici altına alınmalidir; spontan solunum olmayan kalp tepe atım $<100$ atım/dakika hastalarda ise pozitif basınçlı ventilasyona (PBV) bașlanmalıdır. Günümüzde MAS'lı bebeklerde de 2015 'de yeniden düzenlenen uluslararasi neonatal resusitasyon programı (NRP-International Liaison Committee on Resuscitation-ILCOR 2015) önerileri doğrultusunda yaklaşım önerilmektedir (Şekil 2). Doğar doğmaz ağlamayan, hipotonik bebeklere, derin trakeal aspirasyonun faydası olduğuna dair yeterli kanıt günümüzde olmadığından rutinde artık önerilmemektedir. Farklı olarak artık mekonyum deprese bebeklerde de pozitif basınçlı ventilasyon (PBV) önerilmektedir. Önceki yıllarda entübasyon ve derin trakeal temizlik hava yolu obstrüksiyon bulguları olan her hastada rutin olarak önerilirken, günümüzde otoriteler artık bu yaklaşımdan uzaklaşmayı önermektedir (20). Doğum sonrasi solunum yolunun temizlenmesi için izlenecek yol bebeğin derisi ya da solunum yollarında mekonyum olup olmamasına ve bebeğin aktivite düzeyine bağlıdır. Mekonyum boyalı amniotik sıv1 ile doğan ve ileri canlandırma basamakları uygulanan yenidoğanlar yoğun bakıma ünitesine izlem ve gerekirse tedavi için yatırılmalıdırlar (21).

3. Yoğun Bakım Yaklaşımlarında Dikkat Edilmesi Gerekenler: Mekonyum aspirasyonu sendromu olan hastalarda hizlı tan1, iyi tedavi ve bakım ile morbidite ve mortalite azalmıştır. Obstetrik ve yenidoğan ekibi arasındaki iyi koordinasyon ve yönetim MAS gelişme oranını azaltabilir (1). Yoğun bakıma yatırılarak MAS tanısı alan bebeklerde temel tedavi yaklaşımları şu başlıklar altında toplanabilir:

Yeterli oksijenizasyon-ventilasyon, yeterli kan basınc1-perfüzyon akımı sağlanması, metabolik anormallikleri düzeltilmesi, ayrınt1lı nörolojik muayene ve hipoksik iskemik ensefalopati (HİE) evrelemesi yapilarak hastanın hipotermi tedavi endikasyonu açısından değerlendirilmesi, kliniğin yaklaşımına göre hastanın antibiyotik tedavisi açısından değerlendirilmesi, sedatizasyonu (özellikle persistan pulmoner hipertansiyonda, konvülziyonu olan hastalarda antiepileptik tedavi başlamak yoğun bakımda izlenen hastalarda temel tedavi yaklaşımlarını oluşturmaktadır $(15,16,22)$.
Solunum Desteği Yönetimi: Optimal oksijenizasyon ve ventilasyon sağlanarak solunum desteğinin verilmesi temel tedavidir. Aksi taktirde hipoksi, asidoz, hiperkapni pulmoner vasküler direnci arttırabilir ve PPH gelişimine katkıda bulunabilir. Hava kaçakları gelişimi açısindan da dikkatli olmak gerekir. Oksijen desteği hafif-orta MAS'lilarda yeterli olmaktadır $(5,6)$. Ciddi MAS'l hastalarda mekanik ventilasyon desteği, yüksek frekanslı ventilasyon (HFO), sürfaktan tedavisi ve nitrik oksit (NO) tedavisi gerekebilir (7). Mekonyum tıkaçlarının sebep olduğu sekonder sürfaktan eksikliği nedeniyle hastalara respiratuvar distress sendromu (RDS) eşlik edebileceği unutulmamalıdır. Konvansiyonel ve yüksek frekanslı ventilasyon tedavilerine yanit vermeyen $\mathrm{OI}>40$ olan hastalarda ekstrakorporeal membran oksijenasyonu (ECMO) imkanlar ölçüsünde düşünülmelidir. Inflamasyonu baskılayıcı yeni ilaç tedaviler üzerindeki araştırmalar ise halen devam etmektedir $(8,15)$. Tanı konulduktan sonra yeterli oksijenizasyonu sağlamak ve hiperoksi kaynaklı akciğer hasarını azaltmak için arteryel kanda $\mathrm{PaO}_{2}$ (55-90) olacak şekilde satürasyonu $\mathrm{SaO}_{2}$ $>\% 90$ tutulmalıdır. Sürfaktan MAS'lı mekanik ventilatördeki hastalarda solunum hastalığı şiddetini azaltmak ve mekonyuma bağlı sekonder sürfaktan eksikliğini tedavi etmek için kullanılmaktadır $(5,23)$. Ortalama hava yolu basinc1 (MAP) ihtiyac1 >10-12 üzerinde, FiO2 ihtiyac1 $>\% 40$ üzerine çıktığında sürfaktan uygulaması önerilmektedir (24). Bronkoalveloler lavaj bir diğer tedavi seçeneğidir. Yararlığı konusunda farkl1 görüşler mevcuttur. Son derlemelerde sürfaktan ile bronkoalveolar lavaj yapılmasının MAS'in mortalite ve morbiditesini azaltmaktaki yararlılığın tartışmalı olduğunu bildirilmektedir. Sürfaktan lavajı ile beraber ECMO tedavisi uygulananlarda ölüm oranları arasında bir fark bulunmamıştır. Ventilatördeki hastalarda sürfaktan lavaj1 uygularken ciddi komplikasyonlar gelişebileceği de unutulmamalıdır $(24,25)$.

Dolaşımsal Destek Tedavisi: Yeterli kardiyak akımı ve doku perfüzyonunu sağlamak için dolaşımsal destek oldukça önemlidir. Hastaların vital bulguları yakın takip edilmelidir. Şiddetli MAS'li olgularında enteral beslenme kesilebilir ancak bu konuda bir fikir birliği yoktur. Ağır vakalarda doku perfüzyonunu sağlamak amaciyla hemoglobin $>15 \mathrm{~g} / \mathrm{dl}$ 'nin, hematokrit $>\% 40-45$ ' in üstünde tutulmasının faydalı olabileceği ileri sürülmektedir. Hastaların hipotansiyon açısından yakın takibi yapılmalı, gereksinim halinde inotrop destek verilmelidir (24).

Hipotermi Tedavisi: Nörolojik değerlendirme MAS'lı hastalarda solunum desteğinden sonra gelen en önemli değerlendirmedir. Mekonyum aspirasyon sendromlu hasta yaşamının ilk 
6 saati içerisinde asfiksi bulguları gösteriyorsa hipoksik iskemik ensefalopatinin (HIE) Sarnat-Sarnat evrelemesine göre evresi yapıldıktan sonra hipotermi tedavi endikasyonu açısından değerlendirilmelidir (22).

Antibiyotik Kullanımı: MAS'lı hastalarda antibiyotik kullanım yararlığı tartışmalıdır. Randomize kontrollü yapılan bir çalışmada antibiyotik başlamanın kültür pozitif sepsis oranını azaltmadığ 1 görülmüştür. Buna nedenle rutin olarak antibiyotik tedavisi başlanması önerilmez (26).

Steroid Kullanımı ve Antinflamatuar Tedavi: Kortikosteroidler MAS'ın şiddetini azaltmak için önerilmiş olmasına ragmen etkinlikleri konusunda yeterli veri yoktur. Mekonyumun kompleman sistemini aktive ettiği yapılan çalışmalarda kanıtlanmış ve gelecek yıllarda C1 kompleman inibibitörünün bu alanda kullanılabileceği tartışılmaktadır. Aminofilin, clara protein, monoklonal anti-mannoz bağlayan lektin, Caspas-3 inhibitör ve C-1 ajanlar üzerinde yapılan hayvan çalışmaları ise devam etmekte$\operatorname{dir}(15,27,28)$.

Sedasyon: Sedasyonun temel amaci hastalığın akut fazında en iyi gaz alışverişini sağlayabilmektir. MAS'lu hastaların solunum sikıntısı ventilatörle sekronize olmadığında kötüleşebilir. Ajitasyon katekolamin artışı, artan pulmoner vasküler rezistans, sağ-sol şant ve hipoksemiyi daha da ağırlaştırabilir. İntravenoz morfin sulfat, intravenöz fentanil sedasyon ve ağrı için kullanılmaktadır. Senkronize olmayan solunum döngüsü devam ederse ve hava kaçağ1, hava yolu tıkanıklığı gibi bir neden bulunamamişsa noromuskuler blokaj yapan pankuranium tercih edilebilir $(6,7)$.

Nitrik Oksit: Nitrik oksit (iNO) selektif bir pulmoner vazodilatatör olup MAS'na sekonder gelişen PPH'da kullanılır. İnhale NO'in temin edilemediği durumlarda fosfodiesteraz inhibitörü olan sildenafil veya magnezyum sülfat gibi diğer vazodilatatör tedavi seçenekleri de kullanilabilir (29).

Ekstrakorporeal Membran Oksijenasyonu: Mekanik ventilasyon, sürfaktan tedavisi ve/veya iNO tedavisine yanit vermeyen bebeklerde ECMO diğer yaşam kurtarıcı bir tedavi seçeneğidir $(24,29)$.

Salin ile Akciğer Lavajı: Salin ile akciğer lavaji uygulamasındaki amaç aspire edilen mekonyumun havayollarından uzaklaştırılması ve mekanik obstrüksiyon ve enflamasyona bağ11 belirtilerin azaltılmasıdır. Yapılan çalışmalarda $15 \mathrm{ml} / \mathrm{kg}$ salin ile lavajın $\mathrm{pO}_{2}$ 'yi azaltt1ğ 1 ve hyalin membran oluşumunu artırdığının saptanması üzerine daha düşük hacimlerle (8$10 \mathrm{ml} / \mathrm{kg}$, üçe bolunmuş dozda) yapılan salin lavajında \%12 oranında solübl mekonyumun, $\% 5$ oranında da insolubl komponentlerin geri aspire edildiği gösterilmiştir. Salin lavajından sonra verilen sürfaktanla akciğer fonksiyonlarının daha belirgin düzeldiği saptanmıştır (30).

Postural Drenaj ve Fizyoterapi: Fizyoterapi yöntemlerinden postural drenaj, perküsyon ve vibrasyon gibi uygulamalar mekonyumu akciğerlerden uzaklaştırmada faydalı olabilir. Yenidoğanlar için tasarlanmış özel perkütörler kullanılarak yapılan fizyoterapi ile faydalı sonuçlar alınabileceği belirtilmiştir $(1,7,16)$.

Ayırıcı Tanı: Ayırıcı tanıda yenidoğanın geçici takipnesi, persistan fetal sirkülasyon, pnömoni, sepsis, pulmoner hipertansiyon, pulmoner ödem, pnömotoraks, hipovolemi, kan aspirasyonu gibi durumları gözden geçirmek gerekir $(4,17)$.

Mortalite ve Morbidite: Araştırmalarda amniyotik sivida mekonyum ve fetal distres bulguları olan hastalarda perinatal mortalite \%3-22.2, neonatal mortalite ise \%7-50 saptanmiştır. Postmatüritenin engellenmesi, amniyoinfüzyon gibi tedaviler ve yenidoğan bakımı alanındaki gelişmeler ile morbiditesi ve mortalitesi azalmakla birlikte halen önemini koruyan bir konudur $(6,7)$. Amerika Birleşik Devletlerinde yapılan geniş serili bir araştırmada MAS'da mortalite \%1.2 saptanmıştır. Áğır pulmoner parenkim infiltrasyonu ve pulmoner hipertansiyonu olan hastalarda mortalitenin \%20 'lere kadar yükseldiği görülmüştür. Mortaliteyi etkileyen hava kaçağı sendromları ve pulmoner interstisyel amfizem \%10-30 oranında gözlenmektedir. Böbrek yetmezliği, intestinal iskemiye bağlı nekrotizan enterokolit, hipoksiye bağl1 karaciğer fonksiyon testlerinde ve koagulasyon sisteminde bozulma, sürrenal kanama, sepsis bu hastalarda morbidite ve mortaliteyi etkileyen başlıca diğer ek sorunlardır $(8,16)$. Yaşayanlarda nörogelişimsel gerilik mekonyum aspirasyonundan ziyade intrauterin dönemde amniyon sıvısına geçen ve aspire edilen mekonyumun yarattığı kronik hipoksi ve asidoza bağlanmaktadir. Mekonyum aspirasyon sendromlu hastaların uzun dönem nörogelişimsel izlemlerinde serebral palsi, konvülziyon ve zeka geriliğinin daha fazla olduğu bildirilmektedir (17).

Korunma: Mekonyum aspirasyon sendromu, gelişebilecek sonuçları nedeniyle hem prenatal hem de postnatal dönemde iyi yönetilmesi gereken bir durumdur. Dikkatli antenatal takip fetal hipoksinin önlenmesinde birinci derece önem taşır. Bu süreçte riskli gebeliklerin belirlenmesi ve biyofizik skorlama ile fetal intrauterin distresin takibi dikkatli yapılmalıdır $(18,19)$. Postmatüritenin engellenmesi bir diğer önemli noktadır. Bu nedenle risk taşıyan gebelerde 41. haftadan sonra doğum indüksiyonu düşünülebilir. Ancak, doğum indüksiyonu veya amniyotominin de kendi risklerini beraberinde taşıdığı unutulmamalıdır. Bu yöntemler gebede 
prostaglandin artıșına yol açarak uterin kontraksiyonları arttırabilir ve fetal hipoksiye, amniyotik sıvıya mekonyum çıkışına yol açabilir (20).

Günümüzde s1klığı azalmakla birlikte yenidoğan bilimi için önemini koruyan bir konu olan MAS'da mekonyumlu doğum açısından riskli gebeliklerin zamanında ön görülmesi, mekonyumlu amniyotik sivı saptandığında aspirasyonu engellemeye yönelik girișimlerin yapılması, güncel yaklaşımlar doğrultusunda doğum odasinda hastalara müdahale edecek hekim ve sağl1k personellerinin eğitilmesi, doğum sonrasi izlemlerinin multidisipliner bir yaklaşımla yönetilmesi ile bu hastalarda kısa ve uzun dönem morbidite ve mortalitenin azaltılması mümkün olacaktır.

\section{KA Y N A KL A R}

1. Khazardoost S, Hantoushzadeh S, Khooshideh M, Borna M. Risk factors for meconium aspiration in meconium stained amniotic fluid. J Obstet Gynecol 2007; 577-579.

2. Hansen R, Scott KP, Khan S, Martin JC, Berry SH, Stevenson M, Okpapi A, Munro MJ, Hold GL.First-Pass Meconium Samples from Healthy Term Vaginally-Delivered Neonates: An Analysis of the Microbiota. 2015: 28;10(7).

3. Van Ierland $Y$, de Beaufort AJ. Why does meconium cause meconium aspiration syndrome? Current concepts of MAS pathophysiology. Early Hum Dev 2009; 85: 617-20.

4. Fischer C, Rybakowski C, Ferdynus C, Sagot P, Gouyon JB: A population-based study of meconium aspiration syndrome in neonates born between 37 and 43 weeks of gestation. Int $J$ Pediatr 2012; 321545.

5. El Shahed AI, Dargaville PA, Ohlsson A, Soll R. Surfactant for meconium aspiration syndrome in term and late preterm infants. Cochrane Database Syst Rev. 2014;14;12.

6. Karatekin G, Kesim Dönmez M, Nuhoğlu A. Risk factors for meconium aspiration syndrome. International Federation of Gynecology and Obstetrics 1999:295-297.

7. Singh BS, Clark RH, Powers RJ, Spitzer AR. Meconium aspiration syndrome remains a significant problem in the NICU: outcomes and treatment patterns in term neonates admitted for intensive care during a ten-year period. J Perinatol 2009; 29. 497-503.

8. Choi W, Jeong H, Choi SJ, Oh SY, Kim JS, Roh CR, Kim JH. Risk factors differentiating mild/moderate from severe meconium aspiration syndrome in meconium-stained neonates. Obstet Gynecol Sci. 2015;58(1):24-31.

9. Lindenskov PH, Castellheim A, Aamodt G, Saugstad OD: Meconium induced IL-8 production and intratracheal albumin alleviated lung injury in newborn pigs. Pediatr Res 2005; 57 : 371-377.

10. Zagariya A, Bhat R, Navale S, Vidyasagar D: Cytokine expression in meconium-induced lungs. Indian J Pediatr 2004; 71 : 195-201.

11. De Beaufort AJ, Bakker AC, van Tol MJ, Poorthuis BJ, Schrama AJ, Berger HM: Meconium is a source of pro-inflammatory substances and can induce cytokine production in cultured A549 epithelial cells. Pediatr Res 2003; 54: 491-495.

12. Castellheim A, Pharo A, Fung M, Saugstad OD, Mollnes TE: Complement C5a is a key mediator of meconium-induced neutrophil activation. Pediatr Res 2005; 57: 242-247.
13. Salvesen B, Stenvik J, Rossetti C, Saugstad OD, Espevik T, Mollnes TE: Meconium-inducedrelease of cytokines is mediated by the TRL $4 / M D-2$ complex in a CD14-dependent manner. Mol Immunol 2010; 47: 1226-1234.

14. Salvesen B, Nielsen EW, Harboe M, Saugstad OD, Mollnes TE: Mechanisms of complement activation and effects of C1-inhibitor on the meconium-induced inflammatory reaction in human cord blood. Mol Immunol 2009; 46: 688-694.

15. Lindenskov PH, Castellheim A, Saugstad OD, Mollnes TE. Meconium aspiration syndrome: possible pathophysiological mechanisms and future potential therapies. Neonatology. 2015;107(3):225-30.

16. Kırımi E. Mekonyum Aspirasyon Sendromu. Turkiye Klinikleri J Pediatr Sci 2013; 9: 25-33.

17. Wiedemann JR, Saugstad AM, Barnes-Powell L, Duran K. Meconium Aspiration Syndrome. Neonatal Network 2008; 27 : 81-7.

18. Cleary GM, Wiswell TE. Meconium-stained amniotic fluid and the meconium aspiration syndrome. An update. Pediatr Clin North Am 1998; 45: 511-29.

19. Hofmeyr GJ, Xu H, Eke AC. Amnioinfusion for meconiumstained liquor in labour. Cochrane Database of Sys Rev 2014; 23.

20. Myra H. Wyckoff, Chair; Khalid Aziz; Marilyn B. Escobedo; Vishal S. Kapadia; John Kattwinkel; Jeffrey M. Perlman; Wendy M. Simon; Gary M. Weiner; Jeanette G. Zaichkin Neonatal Resuscitation: 2015 American Heart Association Guidelines Update for Cardiopulmonary Resuscitation and Emergency Cardiovascular Care. Circulation. 2015;132.

21. Wiswell TE, Gannon CM, Jacob J, et al. Delivery room management of the apparently vigorous meconium-stained neonate: results of the multicenter, international collaborative trial. Pediatrics 2000; 105: 1-7.

22. Azzopardi D, Strohm B, Marlow N et al. TOBY Study Group. Effects of hypothermia for perinatal asphyxia on childhood outcomes. N Engl J Med. 2014 Jul 10;371(2):140-9.

23. Bendapudi P, Rao GG, Greenough A. Diagnosis and management of persistent pulmonary hypertension of the newborn. Paediatr Respir Rev. 2015 Jun;16(3):157-61.

24. Qureshi FG, Jackson HT, Brown J et al. The changing population of the United States and use of extracorporeal membrane oxygenation. J Surg Res. 2013 Sep;184(1):572-6.

25. Hahn S, Choi HJ, Soll R, Dargaville PA. Lung lavage for meconium aspiration syndrome in newborn infants. Cochrane Database Syst Rev. 2013 Apr 30;4:CD003486.

26. Goel A, Nangia S, Saili A, et al. Role of prophylactic antibiotics in neonates born through meconium-stained amniotic fluid (MSAF)-a randomized controlled trial. Eur J Pediatr 2015; $174: 237$.

27. Basu S, Kumar A, Bhatia BD, Satya K, Singh TB. Role of steroids on the clinical course and outcome of meconium aspiration syndromea randomized controlled trial. J Trop Pediatr 2007; $53: 331-7$

28. Tripathi S, Saili A. The effect of steroids on the clinical course and outcome of neonates with meconium aspiration syndrome. J Trop Pediatr 2007; 53: 8-123.

29. Bendapudi P, Rao GG, Greenough A. Diagnosis and management of persistent pulmonary hypertension of the newborn. Paediatr Respir Rev. 2015 Jun;16(3):157-61.

30. Hahn S, Choi HJ, Soll R, Dargaville PA. Lung lavage for meconium aspiration syndrome in newborn infants. Cochrane $38-$ 